\title{
CASSAVA PRICE COMPETITIVENESS AND CULTIVATION INTEREST
}

\author{
Kusumah Echo Perdana*, Agustina Duwi \\ Faculty of Economics, Bangka Belitung University, Indonesia \\ *E-mail: echo perdana@ubb.ac.id
}

\begin{abstract}
This study aims to determine how much the price influence toward interest in the cultivation of cassava. The price is determined by price suitability with product quality and price competitiveness. Meanwhile, the interest in cassava cultivation determined by the level of happiness, production costs, and technology in Bangka Regency, Bangka Belitung Province, Indonesia. Respondents in this study were cassava farmers with a total of 153 respondents selected by using the snowball sampling technique. The analysis used in this research is descriptive statistics and multiple regressions. The result of the research is descriptively known that price conformity with product quality according to the respondents is considered unsuitable. Price competitiveness according to the respondents is relatively normal there are no price differences. In the indicators of interest in cultivation, the level of happiness and technology is responded to on a low scale, while production costs are met on a high scale. The knowledge of most cassava farmers in Bangka Regency regarding cassava cultivation should be questioned because they consider the quality of their products is the best, whereas the varieties of seedlings they plant are cassava seeds that have an average quality when compared with the Province of Borneo in Indonesia.
\end{abstract}

\section{KEY WORDS}

Cassava price, cultivation interest in cassava, price competitiveness, cassava seed.

The non-oil and gas sector is one of the sources of state revenue in support of the Indonesian economy. The non-oil and gas sector, mainly from the agricultural sector, contributes substantially to the value of the national Gross Domestic Product (GDP) and the large volume of exports. According to the Indonesian Central Bureau of Statistics (BPS) in 2018, GDP value for agriculture sector over the past few years shows an increasing trend from 2014 to 2017. Given the significant contribution of the agricultural sector to the state, the agricultural sector plays an essential role as a source of state income and employment for the Indonesian government. Tuber commodity in the form of cassava is one of substitute food commodities of Indonesian people in the form of rice which is quite an essential role in supporting food security and raw materials of tapioca starch industry in Indonesia. Cassava has a reasonably good energy value when compared with rice, corn, sweet potatoes, and sorghum (Steyn et al., 2014). Where this cassava contains $60 \%$ water, $25-35 \%$ starch, and protein, minerals, fibre, calcium, and phosphate (Indonesian Ministry of Agriculture, 2016). The development of cassava productivity in Indonesia during 1980-2016 tended to increase, along with the increase of farmers' passion for growing excellent cassava varieties of Gajah.

The growth rate of cassava productivity in Indonesia increased by an average of $2.64 \%$ per year. The productivity of 97.51 quintals/ha in 1980 to 239.13 quintal/ha in 2016 . The last five years productivity (2011-2016) increased by $2.85 \%$, despite a decline in cassava production by 2015 compared to 2014 (Indonesian Ministry of Agriculture, 2016). Production of cassava in 2015 as much as 21.80 million tons of wet bulb decreased by 1.63 million tons $(6.98 \%)$ compared to 2014 . The decline in massive cassava production occurred in Java (East Java, Central Java, and West Java) as much as 1.15 million tons and outside of Java (North Sumatra, South Sulawesi, Maluku, Bangka Belitung Islands and West Nusa Tenggara) of 0.48 million tons. The decrease of cassava production occurred due to the decrease of the harvest area of 53.58 thousand hectares (34\%) and productivity of 4.04 quintal / hectare (1.73\%). Bangka Belitung Islands Province is one of the areas of cassava production centres outside Java Island, and Bangka Regency is one of the largest cassava 
producing areas (520 ha) in the Bangka Belitung Islands. However, the area of harvest area is not in accordance with the production output in 2015 as much as 1314 tons compared to West Bangka Regency which has 12,910 tons of production with a harvest area of 505 ha. The condition of cassava production in Bangka Regency is contradictory or inversely proportional to the result of national cassava analysis, where the decrease of national cassava production in 2015 is due to the decrease of harvested area.

The phenomenon of cassava production in Bangka Regency is the basis of research to investigate the effect of price on the interest of cassava cultivation of farmers. Price is the sum of money that is billed on a product or service, or the sum of the value exchanged by customers to benefit from owning or using a product or service (Kotler and Keller, 2006; Kahneman \& Tversky, 2013; Koller, Goedhart, \& Wessels, 2010). In addition, the price is the amount of money paid for the goods and services, or the amount of value that the consumer redeems in order to benefit from owning or using goods or services (Kotler \& Armstrong, 2013; Larivière et al., 2013; Mimouni-Chaabane, \& Volle, 2010). Price depends solely on company policy, but also pay attention to various things. Low or expensive the price of a product or commodity depends on the specifications and advantages of the product itself are very relative in nature. According to Lamb et al. (2001), the price is what the consumer (buyer) must give to get a product. Price is the most flexible element among the four elements of the marketing mix (Nagle \& Müller, 2017; Casadesus-Masanell \& Ricart, 2010; Grant, 2016). In the sense that the price of cassava is the sum of all the values that farmers trade in order to benefit from having a cassava commodity. According to research that has been widely practised, prices have become a significant factor influencing farmers' choices in growing crops (Karlan et al., 2011; McGuirt et al., 2011; Chiputwa, Spielman, \& Qaim, 2015; Fafchamps \& Minten, 2012). The objective of this research is to identify the influence of price on the interest of cassava cultivation of farmers in Bangka Regency, Bangka Belitung Islands Province, Indonesia.

\section{METHODS OF RESEARCH}

This study uses a descriptive approach. Descriptive statistical methods are statistics used to analyze data by way of describing or describing data that has been accumulated as is without intending to make conclusions that apply to the public or generalization (Sugiyono, 2016). Data collection through research instruments in the form of questionnaires. The data analysis begins with the use of descriptive statistics through the SPSS application to illustrate the profile of the respondents. After a depiction of the respondent's profile, an index number analysis is performed using the average value (Sekaran, U., \& Bougie, R., 2016). This index number is applied to determine the tendency of respondent's answer about the variables studied (Ferdinand, 2014). The value of the index number in this study has an interval to make the result conclusion; the interval can be seen in table 1 below:

Table 1 - Interval scale

\begin{tabular}{lll}
\hline No. & Interval Scale & Information \\
\hline 1. & $1,00-1,80$ & Very low \\
2. & $1,81-2,60$ & low \\
3. & $2,61-3,40$ & Medium \\
4. & $3,41-4,20$ & High \\
5. & $4,21-5,00$ & Very high \\
\hline
\end{tabular}

Source: Adapted from Ferdinand (2014)

Interview method is also conducted by researchers to sharpen the results of the study. Respondents in this study were cassava farmers in Bangka Regency, Bangka Belitung Province, Indonesia with a total of 153 respondents selected by using the snowball sampling technique. 


\section{RESULTS OF STUDY}

This descriptive statistic is a statistical test used to find out the general description of cassava farmers in Bangka Regency. The following descriptive statistic test results can be seen in the following tables:

Table 2 - Profile of respondents

\begin{tabular}{llll}
\hline \multirow{3}{*}{ Gender } & & Frequency & Percent \\
& Male & 85 & 55.6 \\
Age & Female & 68 & 44.4 \\
& Total & 153 & 100.0 \\
& $<20$ years & 6 & 3.9 \\
& $21-30$ years & 31 & 38.3 \\
Level of Education & $31-40$ years & 37.3 \\
& $>41$ years & 59 & 100.0 \\
& Total & 57 & 95.4 \\
& High School & 153 & 2.6 \\
& Diploma & 146 & 2 \\
& Bachelor & 4 & 0 \\
& Master-Doctor & 3 & 100.0 \\
\hline
\end{tabular}

Source: Output SPSS.

Based on Table 2, it is seen that most respondents have male gender (55.6\%). While the age of the respondents was $31-40$ years old $(38.6 \%)$ and at the level of education, most of the respondents had a high school education (95.4\%). From the above data obtained that the farmers in Bangka Regency are still in a productive age with the level of education is still relatively low. Low levels of education will be directly related to technological factors. Where technology is one of the indicators of interest to cultivate cassava. With low education will lead to a lack of knowledge about good and proper cassava management procedures so as to improve production output. The above statement is consistent with the results of interviews with various village heads from each district in Bangka Regency; they talked about the lack of application of the latest technology by cassava farmers when compared to Kalimantan (Borneo) and Lampung provinces in Indonesia. Lack of application of technology causes the production of cassava each period continues to decline and eventually the cassava farmers only consider the cultivation of cassava as a complement to other cultivation plants such as white pepper plants that the people of Bangka Belitung have been accustomed to planting from the colonial era to the present.

In the index number analysis, there are several interval criteria in deciding the average value obtained. These intervals are seen in table 3 below:

Table 3 - Price indicators

\begin{tabular}{|c|c|c|c|c|c|c|c|c|c|}
\hline Frequency & \multicolumn{5}{|c|}{ Answer } & \multirow[b]{2}{*}{$N$} & \multirow{2}{*}{$\begin{array}{l}\text { Total } \\
\text { Score }\end{array}$} & \multirow{2}{*}{$\begin{array}{l}\text { Mean } \\
\text { Score }\end{array}$} & \multirow[b]{2}{*}{ Conclusion } \\
\hline Item & $\begin{array}{c}\text { Strongly } \\
\text { Agree (5) }\end{array}$ & $\begin{array}{c}\text { Agree } \\
\text { (4) }\end{array}$ & $\begin{array}{c}\text { Less } \\
\text { Agree (3) }\end{array}$ & $\begin{array}{c}\text { Not Agree } \\
(2)\end{array}$ & $\begin{array}{c}\text { Strongly Not } \\
\text { Agree (1) }\end{array}$ & & & & \\
\hline$X_{1}$ & 2 & 12 & 20 & 105 & 14 & 153 & 342 & 2.23 & Low \\
\hline$x_{2}$ & 31 & 98 & 22 & 2 & 0 & 153 & 617 & 4.03 & High \\
\hline
\end{tabular}

Source: Data processed by researchers.

Based on the above price indicator value, it can be seen that the average value of price conformance indicator with product quality $\left(X_{1}\right)$ has a value of 2.33 and the average indicator value of price competitiveness $\left(X_{2}\right)$ is 4.03 . The average value of the price conformance indicator is included in the low category. It proves that the price offered by the middlemen and the factory is not very much in line with the expectations of the cassava farmers in Bangka Regency. While the price competitiveness indicator included in the high category, this is because the offering price of each middleman and factory is relatively the same, although different only around Rp 25-50 according to interviews from each cassava farmer. 
Price determination by middleman based on price quote determined by tapioca factory located in Bangka Regency. The number of middlemen in Bangka Regency is relatively large, wherein one village there are some cassava middlemen. Based on interviews with some middlemen, it is found that at present they have difficulties in obtaining cassava yield from farmers because the existing farmers complain about the decrease of production which each period is more pronounced and the price is not as expected. Along with the decline in the number of cassava production by farmers, some cassava middlemen have switched to become more prospective middlemen of other agricultural commodities.

Respondents' answers about prices not in accordance with product quality will be inversely proportional to the statement of interviews from several village heads. The respondents considered that the quality of cassava produced was in the right category. Whereas according to direct observation researchers in the field is still not in right cassava management conditions when compared with Lampung province.

Table 4 - Indicator of happiness, production costs, and technology

\begin{tabular}{|c|c|c|c|c|c|c|c|c|c|}
\hline Frequency & \multicolumn{5}{|c|}{ Answer } & \multirow[b]{2}{*}{$\mathrm{N}$} & \multirow[b]{2}{*}{$\begin{array}{l}\text { Total } \\
\text { Score }\end{array}$} & \multirow[b]{2}{*}{$\begin{array}{l}\text { Mean } \\
\text { Score }\end{array}$} & \multirow[b]{2}{*}{ Conclusion } \\
\hline Item & $\begin{array}{l}\text { Strongly } \\
\text { Agree (5) }\end{array}$ & $\begin{array}{l}\text { Agree } \\
\text { (4) }\end{array}$ & $\begin{array}{c}\text { Less Agree } \\
\text { (3) }\end{array}$ & $\begin{array}{c}\text { Not Agree } \\
\text { (2) }\end{array}$ & $\begin{array}{c}\text { Strongly Not } \\
\text { Agree (1) }\end{array}$ & & & & \\
\hline $\mathrm{Y}_{1}$ & 11 & 23 & 69 & 22 & 28 & 153 & 426 & 2.78 & Medium \\
\hline$Y_{2}$ & 27 & 81 & 37 & 8 & 0 & 153 & 586 & 3.83 & High \\
\hline Y3 & 0 & 6 & 20 & 54 & 73 & 153 & 265 & 1.73 & Very Low \\
\hline
\end{tabular}

Source: Data processed by researchers.

Based on table 4 above, it can be seen the average value of happiness indicator has a value of 2.78 , and the average value of production cost indicator is 3.83 , followed by the value of technology indicators is 1.73. Happiness level indicator shows medium level or may be said because the average value shows the value too low, hence the researcher can conclude that the cassava farmers in Bangka regency less so happy with cassava cultivation. The results of the interviews show similarities in the indicators of happiness, where farmers complain about less favourable prices compared to other agricultural commodities such as white pepper, rubber, and oil palm.

The cost of production in cassava is relatively cheap because of the characteristics of cassava plants that are easy to be cultivated compared to the superior cultivation plants found in Bangka Belitung provinces such as white pepper, rubber and palm oil. Therefore reasonable if the respondents or farmers in Bangka Regency answered indicator cost production is cheap. While on the technological indicator, the respondents considered that cassava technology that is currently applied is still in dangerous condition. It is recognized by respondents because of ignorance of how to cultivate good cassava, so they use the way of cultivation as usually applied by his parents first.

\section{CONCLUSION AND SUGGESTIONS}

Interest in cultivating cassava in Bangka Regency through the indicator of price appropriateness with the quality of cassava and price competitiveness do not seem to be in accordance with the expectations of farmers so it can be concluded that the interest of farmers cultivation in Bangka Regency is still not qualified or low. Price adjustment indicator with quality of cassava seems to need to be reviewed, it is caused by the wrong perception by the respondents, where they think that quality cassava seedlings by way of cultivation that as usually practiced by his parents used to be the same with cultivation of cassava in other provinces, including Lampung and Kalimantan provinces. Lampung Province as a barometer of cassava cultivation on the island of Sumatra has a better way of cultivation compared with most farmers in Bangka Regency. This is because the farmers in Bangka regency consider this cassava is not as a pre-eminent commodity in Bangka Belitung province, so they just try it, and if there is decreasing production and price that is not in accordance with expectations, then they will switch to commodity others that have proven to be more reliable such as white pepper, rubber, and palm oil. 
Price competitiveness offered by middlemen and factories is considered by the respondents to be almost the same. Therefore the answers of the respondents tend to be on a high scale. The level of happiness and technology responded by the respondents with a low enough number, where the occurrence of cassava production decline every period with a relatively unsuitable price, then the lack of knowledge in technology cultivation of cassava today. With the largest tapioca factories found in Bangka Regency should be a stimulus to encourage farmers to cultivate cassava. But the reality in the field, there are only a few farmers who can take advantage of it.

Based on survey results, farmers who use these conditions are farmers who have the level of undergraduate education and have a large enough capital to cultivate cassava. Cassava seeds found in Bangka Regency are distributed by factories nearest to their villages, and those who directly buy cassava seeds from Lampung province in order to have good quality seeds compared to those in Bangka Belitung Province. There is a need for counselling and training to the farmers in Bangka Regency, so they can make cassava as a leading commodity by the Government of Regency and Provincial Government especially on the distribution of high-quality cassava seeds and the latest agricultural technology that can boost the production of cassava in maximum stages.

\section{REFERENCES}

1. BPS Indonesia. (2018). GDP Quarterly Based on Constant 2010 Prices by Industrial Origin. Retrieved from https://www.bps.go.id/linkTableDinamis/view/id/827

2. Bryman, A., \& Bell, E. (2015). Business research methods. Oxford University Press, USA.

3. Steyn, N. P., Mchiza, Z., Hill, J., Davids, Y. D., Venter, I., Hinrichsen, E., \& Jacobs, P. (2014). Nutritional contribution of street foods to the diet of people in developing countries: a systematic review. Public health nutrition, 17(6), 1363-1374.

4. Casadesus-Masanell, R., \& Ricart, J. E. (2010). From strategy to business models and onto tactics. Long range planning, 43(2-3), 195-215.

5. Chiputwa, B., Spielman, D. J., \& Qaim, M. (2015). Food standards, certification, and poverty among coffee farmers in Uganda. World Development, 66, 400-412.

6. Fafchamps, M., \& Minten, B. (2012). Impact of SMS-based agricultural information on Indian farmers. The World Bank Economic Review, 26(3), 383-414.

7. Ferdinand, A. (2014). Metode Penelitian Manajemen. Semarang: Badan Penerbit Universitas Diponegoro.

8. Grant, R. M. (2016). Contemporary strategy analysis: Text and cases edition. John Wiley \& Sons.

9. Indonesian Ministry of Agriculture. (2016). Cassava Outlook 2016. Retrieved from http://epublikasi.setjen.pertanian.go.id/arsip-outlook/81-outlook-tanaman-pangan/429outlook-ubikayu-2016

10. Kahneman, D., \& Tversky, A. (2013). Choices, values, and frames. In Handbook of the Fundamentals of Financial Decision Making: Part I (pp. 269-278).

11. Karlan, D., Kutsoati, E., McMillan, M., \& Udry, C. (2011). Crop price indemnified loans for farmers: A pilot experiment in rural Ghana. Journal of Risk and Insurance, 78(1), 37-55.

12. Kotler, P., \& Armstrong, G. (2013). Principles of Marketing: Student Value Edition. Prentice Hall.

13. Koller, T., Goedhart, M., \& Wessels, D. (2010). Valuation: measuring and managing the value of companies (Vol. 499). John Wiley and sons.

14. Kotler, P., \& Keller, K. L. (2006). Marketing management 12e. New Jersey.

15. Larivière, B., Joosten, H., Malthouse, E. C., Van Birgelen, M., Aksoy, P., Kunz, W. H., \& Huang, M. H. (2013). Value fusion: The blending of consumer and firm value in the distinct context of mobile technologies and social media. Journal of Service Management, 24(3), 268-293. 
16. McGuirt, J. T., Jilcott, S. B., Liu, H., \& Ammerman, A. S. (2011). Produce price savings for consumers at farmers' markets compared to supermarkets in North Carolina. Journal of Hunger \& Environmental Nutrition, 6(1), 86-98.

17. Mimouni-Chaabane, A., \& Volle, P. (2010). Perceived benefits of loyalty programs: Scale development and implications for relational strategies. Journal of Business Research, 63(1), 32-37.

18. Nagle, T. T., \& Müller, G. (2017). The strategy and tactics of pricing: A guide to growing more profitably. Routledge.

19. Sekaran, U., \& Bougie, R. (2016). Research methods for business: A skill building approach. John Wiley \& Sons.

20. Sugiyono. (2016). Metodologi Penelitian Kuantitatif, Kualitatif, dan R\&D. Bandung: CV Alfabeta. 